\title{
Numerical analysis of influence of deep excavations on metro tunnel
}

\author{
Cong Chen \\ Wuhan Metro Group Co., Ltd, Wuhan 430030, China \\ 873540602@qq.com
}

Keywords: deep foundation pit; subway station; numerical simulation.

Abstract. As metro and urban light railway transit projects are rapidly launched in China, land exploitation projects along the railway are increasing too, and lots of new buildings' deep foundation pit work are located around metro station and tunnel protection sphere, the metro station will inevitably be influenced by those engineering constructions. Based on a deep excavation project around the metro tunnel in Wuhan, using Midas GTS software 3d numerical analysis model of deep foundation pit excavation, the simulation results show that tunnel structural maximum displacement occurs in the bottom of foundation pit excavation. It is suggested that foundation pit supporting design should be strengthened in frequency of encryption and monitoring, especially the horizontal displacement of retaining structure, supporting structure internal force and deflection.

\section{Introduction}

With the rapid construction of the urban subway and light rail in China, the development of the land along the subway and light rail line also experiences an upward trend. Therefore, a large amount of foundation pit engineering of these new buildings is located within the scope of subway protection which in turn beaks the stress state and balance of equilibrium of the station and tunnel area of subway. It leads to the redistribution of the stress which would result in the internal force change, and deformation of subway station and tunnel ${ }^{[1-3]}$. On the other hand, there exists a strict requirement of the structure deformation of the running subway. Thus, the influence of deep foundation pit unloading on subway cannot be ignored and must be evaluated precisely during the foundation pit engineering which mean that the maintenance design and the construction technology should be carefully selected and improved in order to ensure subway operating safety. In this field, 3D numerical analysis is widely accepted as the most important mean to realize the stability of the foundation pit $^{[4-6]}$.

The software of Midas GTS has the function of 3D modeling, auto mesh generation and professional geotechnical analysis which has been widely used in the area of geotechnical engineering. Therefore, Midas GTS is adopted in this paper to evaluate the effect of foundation pit excavation on subway.

\section{Engineering project}

Project Overview. The engineering project is located in Wuhan. The ground elevation around the foundation pit of this project is approximately 20.40 meters. The depth of the excavation is 11.75 meters with area of $13.700 \mathrm{~m} 2$. The area and surrounding environment as shown in figure 1, architectural details as shown in table 1. 


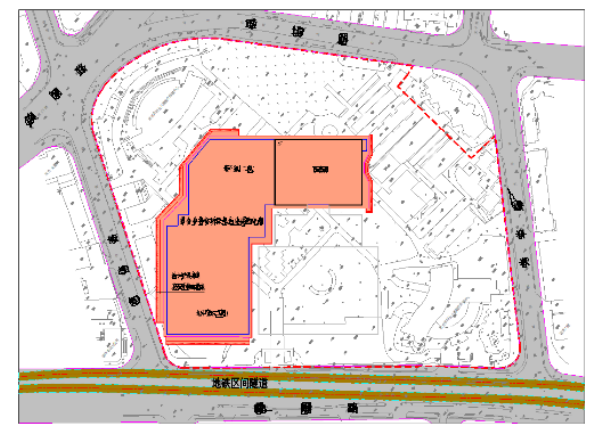

Figure 1 The general plane figure in Wuhan

Table 1 General situation of building

\begin{tabular}{|c|c|c|c|c|c|c|}
\hline $\begin{array}{c}\text { numb } \\
\text { er }\end{array}$ & $\begin{array}{c}\text { name of } \\
\text { buildings }\end{array}$ & $\begin{array}{c}\text { Struct } \\
\text { types }\end{array}$ & $\begin{array}{c}\text { Height } \\
(\mathrm{m})\end{array}$ & $\begin{array}{c}\text { designed } \\
\text { elevation } \\
(\mathrm{m})\end{array}$ & $\begin{array}{c}\text { Embedded } \\
\text { depth of } \\
\text { foundation } \\
(\mathrm{m})\end{array}$ & $\begin{array}{c}\text { Type of } \\
\text { base }\end{array}$ \\
\hline 1 & $\begin{array}{c}\text { superstruct } \\
\text { ure }\end{array}$ & $\begin{array}{c}\text { frame-shea } \\
\mathrm{r} \text { wall } \\
\text { structure }\end{array}$ & $\begin{array}{c}4 /-2 \\
\text { layers } \\
20.10\end{array}$ & $\begin{array}{c}21.10 \\
( \pm 0.00)\end{array}$ & $\begin{array}{c}\text { Pile } \\
\text { foundati } \\
\text { on }\end{array}$ \\
\hline 2 & basement & $\begin{array}{c}\text { frame-shea } \\
\text { r wall } \\
\text { structure }\end{array}$ & $\begin{array}{c}-2 \\
\text { layers }\end{array}$ & $\begin{array}{c}21.10 \\
( \pm 0.00)\end{array}$ & $11.75 \mathrm{~m}$ & $\begin{array}{c}\text { Pile } \\
\text { foundati } \\
\text { on }\end{array}$ \\
\hline
\end{tabular}

This project is close to the subway tunnel. Considering this characteristic and the construction features of the deep foundation pit, it is suggested that during the construction of the project, the foundation pit excavation unloading would lead to negative effects on the subway structure which are mainly embodied in the following two aspects: one is subway structure displacement caused by the excavation; the other one is the stress variation of the subway structure in the excavation. To sum up, using Midas GTS calculation software, combined with the characteristics of the project, the influence of excavation on adjacent metro tunnel structure is simulated and analyzed focused on these three aspects mentioned above.

3D Data Modeling Establishment. According to the spatial relationship between foundation pit and subway, the design of its retaining and supporting structure and the features of construction, the scope of calculation model is based on foundation pit outer contour which means the outside is enlarged at least $30 \mathrm{~m}$ (about 2 times the depth of foundation pit). The boundary conditions of finite element model are as followed: the bottom of the model constraints the vertical displacement and the horizontal displacement is constraints by the left and right sides of the model. Calculation parameters and the network model are shown in table 2 and figure 2 respectively. 
Table 2 The soil parameter

\begin{tabular}{|c|c|c|c|c|c|c|}
\hline $\begin{array}{c}\text { numb } \\
\mathrm{er}\end{array}$ & soil & $\begin{array}{c}\text { The } \\
\text { compress } \\
\text { ion } \\
\text { modulus } \\
(\mathrm{MPa})\end{array}$ & $\begin{array}{c}\text { Poisson } \\
\text { 's ratio }\end{array}$ & $\begin{array}{c}\text { Bulk } \\
\text { density } \\
\left(\mathrm{kN} / \mathrm{m}^{3}\right. \\
)\end{array}$ & $\begin{array}{c}\text { Cohesive } \\
\text { force } \\
(\mathrm{kPa})\end{array}$ & $\begin{array}{c}\text { Angle of } \\
\text { internal } \\
\text { friction }\left({ }^{\circ}\right)\end{array}$ \\
\hline 1 & Grain filling & 3.5 & 0.34 & 18.0 & 10 & 8.0 \\
\hline 2 & Silt clay & 3.0 & 0.35 & 17.0 & 8.6 & 5.3 \\
\hline 3 & $\begin{array}{c}\text { Silt and silty } \\
\text { clay }\end{array}$ & 6.5 & 0.33 & 18.1 & 14.6 & 8.4 \\
\hline 4 & silt & 16.0 & 0.30 & 18.5 & 0 & 32.8 \\
\hline
\end{tabular}

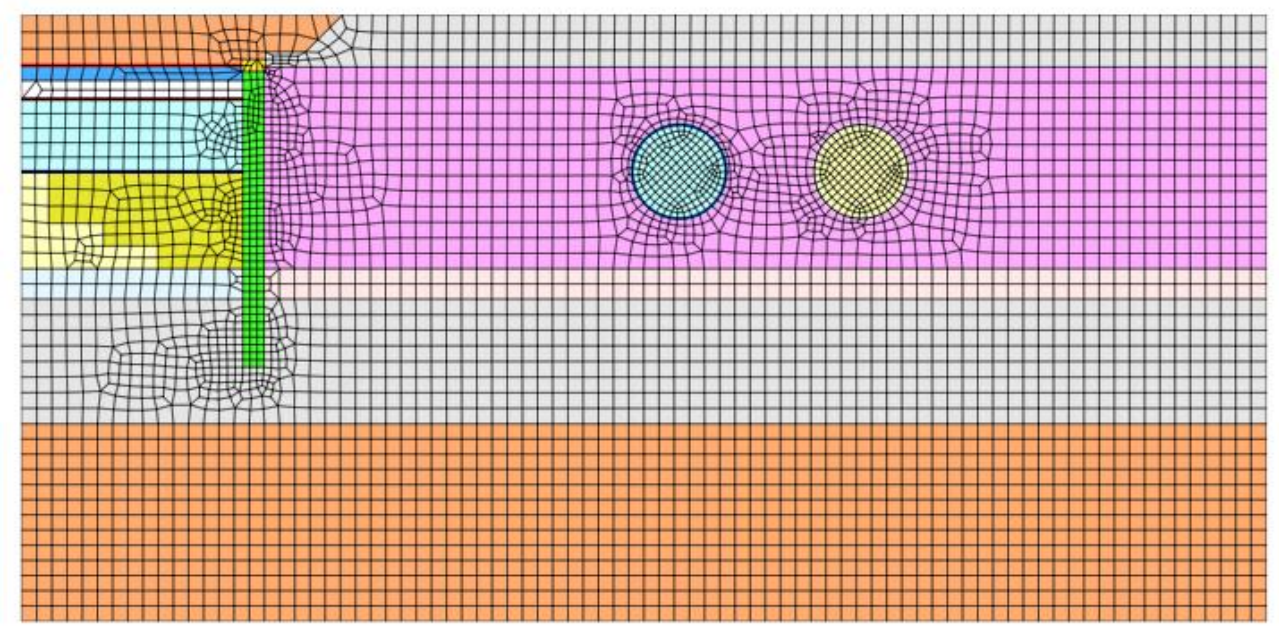

Figure 2 The model of calculation

\section{The Analysis About the Influence of Proposed Project on Metro Tunnel}

The Displacement Analysis About the Influence of Proposed Project on Metro Tunnel. According to numerical calculation, it is concluded that the overall model and the subway interval of horizontal and vertical displacement, as shown in figure 3 and figure 4.

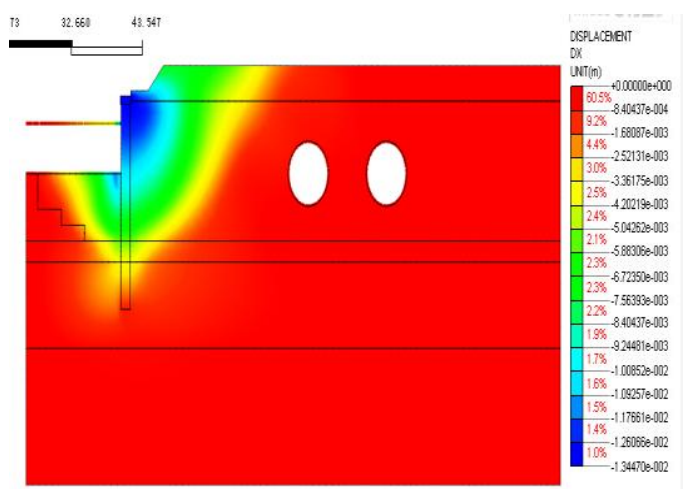

(a) Transverse displacement nephogram

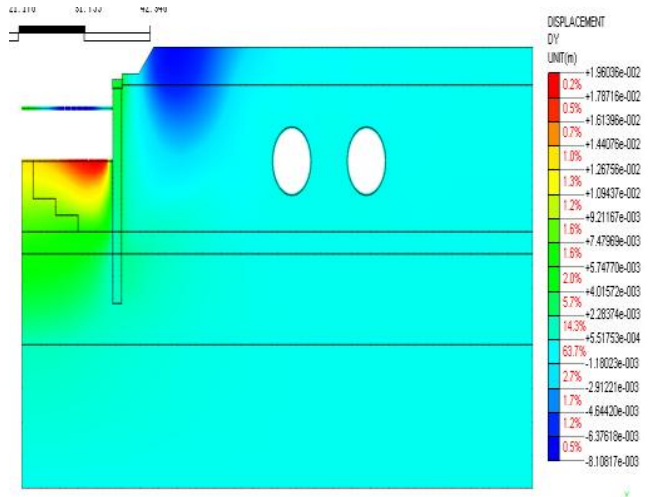

(b) Longitudinal displacement nephogram

Figure 3 The whole model displacement nephogram after the demolition of support 

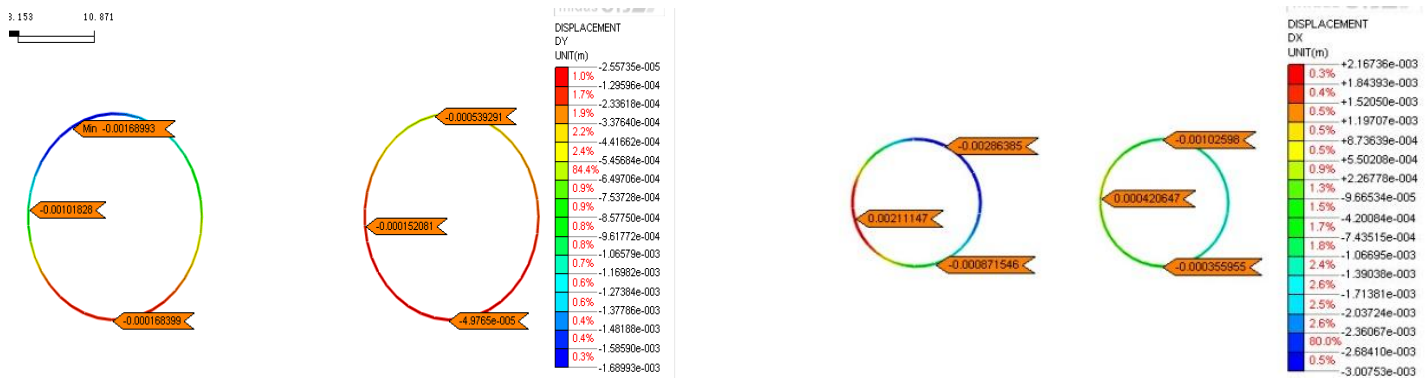

(a) Transverse displacement nephogram

(b) Longitudinal displacement nephogram

Figure 4 The metro tunnel's model displacement nephogram after the demolition of support

In the different cases, the change of tunnel's displacement is shown in table 3 and figure 5 .

Table 3 The change of tunnel's displacement

\begin{tabular}{|c|c|c|}
\hline model & $\begin{array}{c}\text { Horizontal } \\
\text { sedimentation } \\
(\mathrm{mm})\end{array}$ & $\begin{array}{c}\text { Vertica } \\
\text { sedimentation } \\
(\mathrm{mm})\end{array}$ \\
\hline Case 1 & 0 & 0 \\
\hline Case 2 & 0 & 0 \\
\hline Case 3 & -0.26 & -0.2 \\
\hline Case 4 & -0.35 & -0.22 \\
\hline Case 5 & -0.37 & -0.23 \\
\hline Case 6 & -0.46 & -0.26 \\
\hline Case 7 & -2.95 & -1.35 \\
\hline Case 8 & -2.95 & -1.36 \\
\hline Case 9 & -2.95 & -1.36 \\
\hline Case 10 & -3 & -1.69 \\
\hline
\end{tabular}

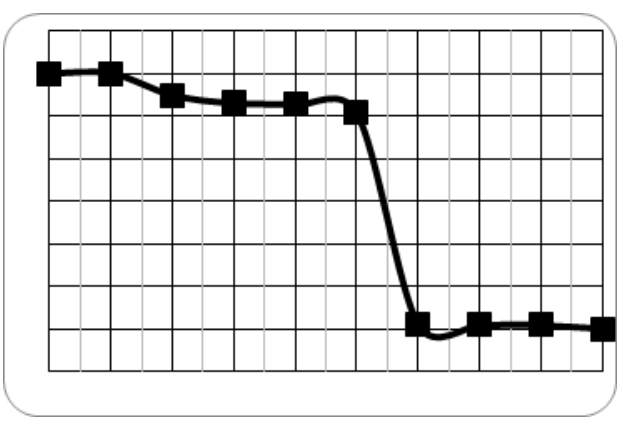

(a) Transverse displacement $\mathrm{x}$ axis-case, $\mathrm{y}$ axis-displacement $(\mathrm{mm})$ axis-displacement $(\mathrm{mm})$

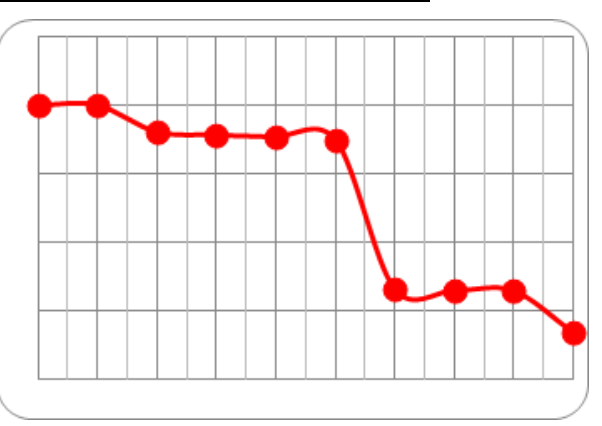

(b) Longitudinal displacement $\mathrm{x}$ axis-case, $\mathrm{y}$

Figure 5 The displacement of tunnel

According to the results of numerical simulation, the influence scope of proposed project on metro tunnel are safety. The structural deformation caused by foundation pit construction meet the requirements 
The Internal Force Analysis About the Influence of Proposed Project on Metro Tunnel. According to numerical calculation, it is concluded that the metro tunnel's internal force, as shown in figure 6 and table 4.

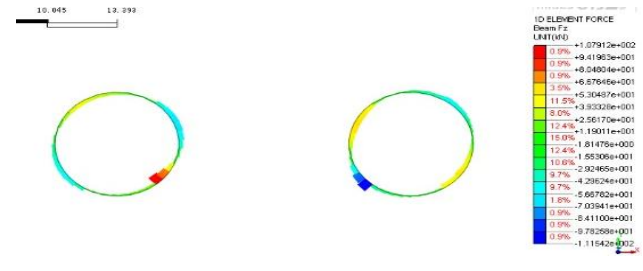

(a) Bending moment diagram

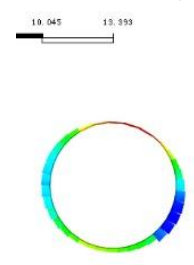

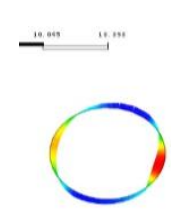
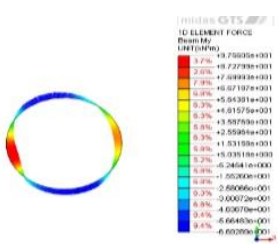

(b) Shear diagram

(c) Axial force diagram

Figure 6 The internal force of structure after excavation

Table 4 The calculation result of tunnel

\begin{tabular}{|c|c|c|c|}
\hline \multirow[b]{2}{*}{ program } & \multicolumn{2}{|c|}{ model } & \multirow{2}{*}{$\begin{array}{c}\text { Reinforce } \\
\text { ment } \\
\text { calculatio } \\
n\end{array}$} \\
\hline & $\begin{array}{l}\text { Before the } \\
\text { excavation }\end{array}$ & $\begin{array}{l}\text { after the } \\
\text { excavation }\end{array}$ & \\
\hline $\begin{array}{c}\text { Bending moment } \\
(\mathrm{kN} \cdot \mathrm{m})\end{array}$ & 94.31 & 97.56 & $\begin{array}{c}\text { meet requi } \\
\text { rement }\end{array}$ \\
\hline Shear $(\mathrm{kN})$ & 109.54 & 111.54 & $\begin{array}{c}\text { meet requi } \\
\text { rement }\end{array}$ \\
\hline Axial force $(\mathrm{kN})$ & 148.37 & 148.84 & $\begin{array}{c}\text { meet requi } \\
\text { rement }\end{array}$ \\
\hline
\end{tabular}

According to the results of numerical simulation, the influence of internal force about proposed project on metro tunnel are safety. The change of structural internal force caused by foundation pit construction meet the requirements

\section{Conclusion}

Taking the construction of the foundation pit near Wuhan urban rail transit line 6 as an example, Midas GTS is used to make the 3D data analysis model based on the real construction project and various situations. According to the data from the model, it is concluded as below.

1) The project of the Integrated Service Building of Wuhan Women and Children Medical and Health Center dose not conflict with the subway tunnel in terms of spatial position. According to the construction sequence, the construction of this project is earlier than the subway tunnel. Therefore, this project has the construction feasibility with necessary engineering safety protection.

2) According to the calculation using finite element method, the structural displacement of the tunnel always happens at the final stage of excavation or the moment 
of foundation pit supporting replacement. As a result, some methods of supporting replacement such as plate and strip should be carefully considered in the design of foundation pit support.

3) With consideration of the risks existing in the construction, it is suggested that foundation pit supporting design should be strengthened in frequency of encryption and monitoring, especially the horizontal displacement of retaining structure, supporting structure internal force and deflection. Special operation monitoring plan should be made at the same time.

\section{Reference}

[1] Sun Jun. Environmental geotechnique problems of urban underground engineering activities (under) [J]. Journal of underground engineering and tunnel, 2000, (1), 2-7.

[2] Michael Long. Database for Retaining Wall and Ground Movements due to Deep Excavations[J]. Journal of Geotechnical and Geoenvironmental Engineering, 2001, vol. 127: 203-224.

[3] Villy A, Kontogianni, Stathis C, Stiros. Induced deformation during tunnel excavation: Evidence from geodetic monitoring[J]. Engineering Geology, 2005, vol. 79: 115-126.

[4] Chen Fuquan, Wang Jinwei, Liu Yuchuan. In the excavation of foundation pit adjacent pile foundation of numerical analysis of the properties of $[\mathrm{J}]$. Rock and soil mechanics, 2008, 29 (7); 1971-1976.

[5] Wang Weidong, Shen Jian, Weng Qiping. Excavation engineering analysis of the adjacent metro tunnel effect and countermeasures [J]. Journal of geotechnical engineering, 2006, 28 (S1) : 1340-1345.

[6] Wang Jianhua, Wu Houxin, Zhou Hongyi. Adjacent to the subway foundation pit supporting engineering design $[\mathrm{J}]$. Journal of exploration engineering (geotechnical drilling and digging engineering), 2011, 38 (11) : 71-75. 